\author{
ANNA MONIKA NOGA \\ Uniwersytet Mikołaja Kopernika w Toruniu \\ ORCID: 0000-0002-6226-5392
}

290408@stud.umk.pl

\title{
Pojęcie wypadku przy pracy w świetle orzecznictwa Sądu Najwyższego
}

\author{
The concept of work accident in the light of the Supreme Court's judicial decision
}

Streszczenie: Możliwość wystąpienia zdarzenia, jakim jest wypadek przy pracy stanowi niemal nieodłączny element każdej aktywności zawodowej. Stąd też bardzo ważnym jest odpowiednie uregulowanie tego pojęcia, zarówno $\mathrm{w}$ ustawach, jak $\mathrm{i}$ w orzecznictwie. Kwalifikacja prawna zdarzenia jako wypadek przy pracy przede wszystkim istotna jest dla poszkodowanego pracownika, bowiem pozwala to na uzyskanie przez niego prawa do odpowiednich świadczeń. Często jednak decyzje w tym zakresie poddawane są w wątpliwość i zaskarżane do sądów powszechnych. Najważniejszą linię orzeczniczą w tego typu sprawach tworzy Sąd Najwyższy.

Celem niniejszego artykułu jest ukazanie ewolucji pojęcia „wypadku przy pracy” na przestrzeni kolejnych ustaw obowiązujących w Polsce, ale w głównej mierze poprzez skupienie się na wyrokach wydawanych przez Sąd Najwyższy. W opracowaniu zostanie omówiona obecnie stosowana definicja wypadku przy pracy oraz jej poszczególne elementy, których wyjaśnienie zostanie poparte orzecznictwem.

Summary: The possibility of work accident occurrence is almost an inseparable element of every professional activity. That is why it is important to regulate this concept properly, both in acts and in judicial decisions. The legal classification of an event as work accident is primarily important for affected employees because it enables them to get the right to gain proper benefits. However, it often happens that decisions in this respect are subject to concern and they are appealed to a common court. In such cases, the most important judicature line is created by the Supreme Court.

The aim of the article is to present the evolution of the "work accident" concept through subsequent acts in Poland, but mainly through the focus on judgements announced by the Supreme Court. A current definition of work accident and its particular elements, which explanation will be supported by judicial decision, will be discussed in the study.

Słowa kluczowe: wypadek przy pracy; elementy definicji wypadku przy pracy; ustawa wypadkowa; ubezpieczenie wypadkowe.

Keywords: work accident; elements of work accident definition; accident act; accident insurance. 


\section{Wstęp}

Zgodnie $\mathrm{z}$ art. 15 Kodeksu pracy $^{1}$ pracodawca ma obowiązek zapewnić pracownikom bezpieczne i higieniczne warunki pracy. Zasada ta ma swoje konotacje w Konstytucji RP, a konkretnie w art. 66 ust. 1, który brzmi następująco: „Każdy ma prawo do bezpiecznych i higienicznych warunków pracy. Sposób realizacji tego prawa oraz obowiązki pracodawcy określa ustawa", jak również w licznych aktach o charakterze ponadnarodowym (np. w Konwencji nr 155 Międzynarodowej Organizacji Pracy dotyczącej bezpieczeństwa, zdrowia pracowników i środowiska pracy z 1981 r.). Jej konkretyzację można odnaleźć w pozostałych przepisach kodeksu, zwłaszcza dotyczących obowiązków pracodawcy, a także w rozporządzeniach wykonawczych czy w obowiązujących Polskich Normach.

Niniejsze opracowanie omawia problematykę pojęcia wypadku przy pracy biorąc pod uwagę konkretne stany faktyczne zawarte w kilkunastu wyrokach Sądu Najwyższego. Stanowią one niejako wyznaczniki kolejnych orzeczeń, przez co tworzą jednolitą linię orzeczniczą.

\section{Legalna definicja wypadku przy pracy}

Rozważania nad ustawową definicją pojęcia ,wypadek przy pracy” należy zacząć od przywołania ogólnego znaczenia wyrazu „wypadek”. Według Słownika języka polskiego pod red. Bogusława Dunaja ${ }^{2}$ słowo to oznacza: „to, co się wydarzyło; zdarzenie; wydarzenie; fakt” oraz „nagłe, niespodziewane zdarzenie, w którego wyniku ktoś poniósł uszczerbek materialny, utracił zdrowie lub życie bądź został narażony na takie niebezpieczeństwo". Wypadek jest zdarzeniem losowym i nieproszonym. W tym szeroko zarysowanym pojęciu mieści się także sformułowanie wypadek przy pracy, które jednak posiada swoje indywidualne cechy. ${ }^{3}$

Zgodnie z art. 137 ustawy z dnia 28 marca 1933r. o ubezpieczeniu społecznym ${ }^{4}$ „[1] za wypadki w zatrudnieniu należy uważać wypadki przy pracy, tudzież wypadki przy domowych lub innych zajęciach, do których ubezpieczony został użyty przez pracodawcę lub inną osobę, której podlega z powodu swego zatrudnienia. [2] To samo dotyczy wypadków przy przechowywaniu, czyszczeniu, naprawie i przenoszeniu narzędzi pracy, chociażby dostarczanych przez zatrudnionego. [3] Za wypadki w zatrudnieniu uważać należy wreszcie wypadki w drodze do pracy i z pracy [...]”. Jak można zauważyć, ustawa z 1933 r., której

\footnotetext{
${ }^{1}$ Ustawa z dnia 26 czerwca 1974 r. Kodeks pracy, t.j. Dz. U. z 2020 r. poz. 1320.

${ }^{2}$ B. Dunaj, Stownik języka polskiego, Wydawnictwo Twoje Książki, Warszawa 2008, s. 566.

${ }^{3}$ L. Florek, Prawo pracy, Wydawnictwo C.H.Beck, Warszawa 2016, s. 352-353.

${ }^{4}$ Dz.U. 1933 nr 51 poz. 396.
} 
zadaniem było uchylenie obowiązujących aktów prawnych państw zaborczych oraz ujednolicenie zasad podlegania ubezpieczeniu wypadkowemu dla całego terytorium Polski, nie zawierała stricte definicji wypadku przy pracy. Określała ona ogólne sformułowanie „wypadek w zatrudnieniu”, poprzez przytoczenie poszczególnych rodzajów zdarzeń, jednak nie precyzując ich cech czy przebiegu.

Po II wojnie światowej w Dekrecie z dnia 25 czerwca 1954 r. ${ }^{5}$ zawarto już określoną definicję wypadku w zatrudnieniu. W art. 36 wskazano, iż „za wypadek W zatrudnieniu uważa się nagłe zdarzenie spowodowane przyczyną zewnętrzną, które zaszło w związku z zatrudnieniem”. W ustępie 2 natomiast zwrócono uwagę, jakie wypadki W szczególności uważa się za pozostające w związku z zatrudnieniem, m.in. podczas lub W związku z wykonywaniem swoich zwykłych czynności albo poleceń osób, którym pracownik podlega $\mathrm{z}$ tytułu swego zatrudnienia. Kolejne ustawy powielały jedynie przytoczoną definicję. ${ }^{6}$

Warto podkreślić, iż objaśnienie występujące w polskim prawie przed $2003 \mathrm{r}$. wzbudzało wiele wątpliwości interpretacyjnych. Przede wszystkim zwracano uwagę, że w definicji z 1954 r. brakowało elementu szkody na osobie pracownika, co wywodziło się z interpretacji jakiej dokonano na Pierwszej Konferencji Przewodniczących Sądów Rozjemczych dla spraw byłego Zakładu Ubezpieczeń od Wypadków z 3.09.1931 r., a która zawierała sformułowanie, że „Jako nieszczęśliwy wypadek należy uważać każde nagłe zdarzenie, wywołane przyczyną zewnętrzną, które zaszło z powodu pracy i wywołało pośrednio śmierć, względnie obrażenie ciała lub chorobę pracownika". Poza tym, w praktyce, wykorzystując tę definicję, można było za wypadek przy pracy uznać każde zdarzenie fizyczne, mające miejsce na terenie zakładu pracy, nie zważając na kwestię czy pracownik doznał realnej szkody. ${ }^{8}$

W związku z powyższym, na gruncie obowiązującej obecnie ustawy wypadkowej ${ }^{9}$ z 30 października 2002 r., uzupełniono brakujący element definicji wypadku przy pracy. Zgodnie bowiem z art. 3 ust. 1 wspomnianej ustawy: ,za wypadek przy pracy uważa się nagłe

\footnotetext{
${ }^{5}$ Dekret z dnia 25 czerwca 1954 r. o powszechnym zaopatrzeniu emerytalnym pracowników i ich rodzin, Dz. U. 1954 nr 30 poz. 116.

${ }^{6}$ M. Jachimowicz, Wypadki przy pracy $i$ choroby zawodowe. Świadczenie ubezpieczeniowe $i$ cywilne, wyd. Difin, Warszawa 2013, s. 14.

7 I. Jędrasik-Jankowska, Pojęcia i konstrukcje prawne ubezpieczenia społecznego, wyd. Wolters Kluwer, Warszawa 2018, s. 403-405.

${ }^{8}$ Tamże, s. 406.

${ }^{9}$ Ustawa z dnia 30 października 2002 r. o ubezpieczeniu społecznym z tytułu wypadków przy pracy i chorób zawodowych, Dz. U. 2002 nr 199 poz. 1673.
} 
zdarzenie wywołane przyczyną zewnętrzną powodujące uraz lub śmierć, które nastąpiło w związku z pracą:

1) podczas lub w związku z wykonywaniem przez pracownika zwykłych czynności lub poleceń przełożonych;

2) podczas lub w związku z wykonywaniem przez pracownika czynności na rzecz pracodawcy, nawet bez polecenia;

3) $\mathrm{w}$ czasie pozostawania pracownika w dyspozycji pracodawcy w drodze między siedzibą pracodawcy a miejscem wykonywania obowiązku wynikającego ze stosunku pracy.

Jak wynika z zacytowanego przepisu, na pojęcie wypadku przy pracy składają się cztery elementy:

1) nagłość zdarzenia

2) zewnętrzność przyczyny

3) związek zdarzenia z pracą

4) skutek w postaci szkody jaką jest uraz lub śmierć.

Nie ma wątpliwości, że zdarzenie, które kwalifikuje się jako wypadek przy pracy musi spełniać łącznie powyższe przesłanki. Należy jednak zauważyć, że każdy z wyżej wymienionych punktów pozostawia pewną przestrzeń interpretacyjną, zarówno dla doktryny jak i orzecznictwa. W dalszej części zostaną omówione poszczególne punkty świetle wyroków Sądu Najwyższego.

\section{Nagłość zdarzenia}

Według L. Florka zdarzeniem nagłym jest niespodziewane doznanie przez człowieka urazu cielesnego, przy czym zaskakującą nie jest sama przyczyna danego urazu, ponieważ w wyjątkowych przypadkach może ją stanowić stopniowo nasilający się czynnik. ${ }^{10}$ Przyjmuje się, iż cechę nagłości ma zdarzenie trwające nie dłużej niż jedną dniówkę roboczą, co zapoczątkował wyrok Trybunału Ubezpieczeń Społecznych z dnia 19 września 1958 r. (nr IR III 140/58). Poprzez tak zarysowaną granicę, do wypadków przy pracy zalicza się nie tylko zdarzenia gwałtowne, np. uraz spowodowany upadkiem z wysokości, lecz także mające przebieg dłuższy, do których należą m.in. urazy wyrządzone promieniowaniem czy działaniem substancji chemicznych.

Problematyką nagłości wypadku przy pracy wielokrotnie zajmował się Sąd Najwyższy. W wyroku z dnia 5 października 2012 r. ${ }^{11}$ przedmiotem postępowania była

\footnotetext{
10 L. Florek, Prawo pracy, ....s. 353.

${ }^{11}$ Wyrok SN z dnia 5 października 2012 r., I UK 197/12, LEX nr 1303225.
} 
sprawa kasjerki, która doznała urazu odwarstwienia siatkówki oka. Skarżąca twierdziła, iż szkoda ta powstała konkretnego dnia pracy podczas przesuwania zgrzewki z wodą o wadze około $10 \mathrm{~kg}$. Pracodawca jednak nie uznał opisanego zdarzenia za wypadek przy pracy. Powołana w sprawie biegła okulistka w swojej opinii wykazała, że już dwa dni przed wskazanym dniem, poszkodowana miała początkowo niewielkie, ale stopniowo nasilające się odwarstwienie siatkówki oka. Z opinii wynikało zatem, iż przesunięcie zgrzewki z wodą nie spowodowało urazu, a stanowiło jedynie zbieg okoliczności. Sąd Najwyższy w opisanej sprawie podkreślił, że „Warunkiem odpowiedzialności na podstawie ustawy wypadkowej jest ustalenie wypadku przy pracy w określonym dniu (...). W orzecznictwie zasadnie przyjmuje się, że negatywne działanie przyczyny zewnętrznej na organizm pracownika, którego skutkiem jest wystąpienie wypadku przy pracy (czyli urazu lub śmierci), ograniczone jest tylko do jednej dniówki roboczej. Trafnie stwierdzono, że przesłanka nagłości zdarzenia kreująca pojęcie prawe wypadku przy pracy, oznacza, co do zasady krótkie, momentalne, jednorazowe lub gwałtowne zadziałanie tej przyczyny zewnętrznej. Nagłość stanowi zaprzeczenie powolnego rozwoju lub kumulowania się objawów charakterystycznych dla chorób zawodowych lub pracowniczych". Powyższe orzeczenie w sposób wyczerpujący opisuje cechę nagłość zdarzenia, jakim jest wypadek przy pracy.

Warto przytoczyć w tym miejscu także inny wyrok SN, który pozwoli lepiej zrozumieć cechę nagłości w kontekście wypadku przy pracy i choroby zawodowej. W orzeczeniu z dnia 4 października 2006 r. ${ }^{12}$ Sąd Najwyższy stwierdził, iż „Uzależnienie uznania zdarzenia za wypadek przy pracy od wymagania, by było zdarzeniem nagłym nie dlatego, że przebiega momentalnie, lecz że jest wynikiem - będącego przyczyną wypadku krótkotrwałego działania zewnętrznego na organizm pracownika stanowi użyteczny argument dla rozgraniczenia ryzyka wypadku przy pracy od ryzyka zachorowania na chorobę zawodową.”. I. Jędrasik-Jankowska ${ }^{13}$ podkreśla jednak, że wbrew pozorom nagłość nie stanowi kryterium rozróżniania pojęć choroba zawodowa i wypadek przy pracy, bowiem elementem oddzielającym jest w tym przypadku związek urazu lub śmierci z pracą.

Ciekawą kwestią związaną z cechą nagłości jest problematyka wypadku przy pracy mającego postać zawału serca. W wyroku z dnia 11 stycznia 2013 r. ${ }^{14}$ rozpatrywano sprawę pracownika, który w czasie wykonywania zwykłych czynności związanych z zatrudnieniem, zasłabł i zmarł. W szpitalu stwierdzono świeży, rozległy zawał ściany przedniej serca

\footnotetext{
${ }^{12}$ Wyrok SN z dnia 4 października 2006 r., II UK 40/06, LEX nr 309429.

${ }^{13}$ I. Jędrasik-Jankowska, Pojęcie $i$ konstrukcje prawne..., s. 410-411.

${ }^{14}$ Wyrok SN z dnia 11 stycznia 2013r., II UK 162/12, LEX nr 1314610.
} 
powikłany migotaniem komór, natomiast przeprowadzona następnie sekcja zwłok wykazała miażdżycę, rozległy zawał mięśnia sercowego oraz mniejszą miażdżycę pozostałych tętnic wieńcowych. Zarówno sąd I, jak i II instancji doszedł do wniosku, że powyższemu zdarzeniu nie można przypisać cechy "nagłości" oraz tego, iż zostało ono wywołane przyczyną zewnętrzną. Sąd Najwyższy uznał jednak skargę kasacyjną w tej sprawie za zasadną oraz zauważył, iż: " (...) w judykaturze SN wyrażany jest pogląd, że dla uznania zdarzenia za wypadek przy pracy nie wymaga się jednoczesnego wystąpienia przyczyny i skutku. Cecha nagłości odnosi się do czasu trwania zdarzenia, a nie do czasu oddziaływania przyczyny zewnętrznej. Jedynie czas trwania zdarzenia (a nie oddziaływania przyczyny) ogranicza się do dniówki roboczej. Wypadek przy pracy przybierający postać zawału serca może być wynikiem wpływu czynników zewnętrznych pozostających w związku z pracą na rozwijające się samoistnie schorzenie kardiologiczne. W takim przypadku kumulowanie się tych negatywnych dla zdrowia pracownika czynników i ich przerodzenie się w sprawczą przyczynę wypadku przy pracy nie musi przebiegać w ciągu jednego dnia pracy. Zewnętrzną przyczyną zdarzenia (tu: zawału serca) może być zatem wykonywanie pracy w normalnych warunkach, jeśli ze względu na stan zdrowia pracownika powodowały one nadmierne obciążenie jego organizmu, przy uwzględnieniu całego okresu, przez który praca nieodpowiadająca stanowi zdrowia pracownika była wykonywana, a nie tylko dzień, w którym zdarzenie nastąpiło.”

Kończąc rozważania na temat cechy nagłości należy zwrócić uwagę na wielość możliwości interpretacyjnych związanych z tym elementem pojęcia wypadku przy pracy. Sądy powinny zatem pochylić się nad każdym stanem faktycznym i indywidualnie zbadać tę kwestię. Szeroko rozumiana nagłość może wpływać pozytywnie na sytuację ubezpieczonego, bowiem często pozwala to na wydanie orzeczenia na korzyść poszkodowanego.

\section{Zewnętrzność przyczyny}

Definicja wypadku przy pracy zawarta w art. 3 ustawy wypadkowej narzuca, aby przyczyna zewnętrzna wywoływała zdarzenie, które stanowi przyczynę urazu lub śmierci pracownika. Można zatem wywnioskować, iż wymaga się tutaj zbadania dwóch związków przyczynowoskutkowych, mianowicie: między przyczyną zewnętrzną a zdarzeniem oraz między zdarzeniem fizycznym a szkodą, której uległ poszkodowany. ${ }^{15}$ Tak zarysowana struktura

\footnotetext{
${ }^{15}$ A. Góraj, Wypadek przy pracy - sytuacja prawna ubezpieczonego w świetle aktualnej definicji, „Przegląd Prawniczy Uniwersytetu Warszawskiego Rok XVI, nr 1/2017, s. 125.
} 
budzi pewne wątpliwości interpretacyjne, które wielokrotnie stają się przedmiotem orzecznictwa sądowego.

W wyroku Sądu Najwyższego z dnia 6 sierpnia 2014 r. ${ }^{16}$ uznano, że przyczyną zewnętrzną kwalifikującą zdarzenie jako wypadek przy pracy może być niezapewnienie pracownikowi przez pracodawcę należytej opieki medycznej, również kiedy nie było to zawinione. Poszkodowany pracownik doznał udaru niedokrwiennego mózgu w trakcie pracy wykonywanej w Belgii dnia 11 lipca 2019 r. prawdopodobnie ok. godz. $9^{00}$, natomiast dopiero 12 lipca o godz. $2^{30}$ został przewieziony przez pracodawcę pod granicę, skąd odebrali go rodzice i zawieźli do najbliższego szpitala. Sąd Najwyższy przypomniał, że: „Z niedookreślonego charakteru wyrażenia przyczyna zewnętrzna wynika, iż przyczyną zewnętrzną wypadku przy pracy może być każdy czynnik zewnętrzny (niewynikający z wewnętrznych właściwości człowieka) zdolny wywołać w istniejących warunkach szkodliwe skutki. W tym znaczeniu taką przyczyną może być także praca i czynność samego poszkodowanego, w tym zwłaszcza jego nadmierny wysiłek, za który u człowieka dotkniętego schorzeniem samoistnym może być uważana praca wykonywana także jako codzienne zadanie w normalnych warunkach, nadmierność bowiem wysiłku pracownika powinna być oceniona przy uwzględnieniu jego indywidualnych właściwości”. Jak widać w orzecznictwie bardzo szeroko rozpatruje się kwestię przyczyny zewnętrznej wypadku przy pracy. Podkreślenia wymaga istotność niejako dostosowania czynnika nadmiernego wysiłku indywidualnie do danego pracownika. Problem ten porusza także postanowienie SN z 16 stycznia 2014r. ${ }^{17}$, w którym to stwierdzono, że „Co do zasady wykonywanie zwykłych (typowych, normalnych), choćby stresujących lub wymagających dużego wysiłku fizycznego, czynności (obowiązków) przez pracownika, który doznał zasłabnięcia w czasie i miejscu wykonywania zatrudnienia, nie może być uznane za zewnętrzną przyczynę wypadku przy pracy, gdyż sama praca nie może stanowić zewnętrznej przyczyny w rozumieniu definicji wypadku przy pracy, ale może nią być dopiero określona nadzwyczajna sytuacja związana $\mathrm{z}$ tą pracą, która staje się współdziałającą przyczyną zewnętrzną. Dopuszcza się jednak wyjątkowo, że nawet codzienne czynności wykonywane w normalnych warunkach przez pracownika o zmniejszonej sprawności, czy to na skutek choroby, czy też w wyniku postępujących zmian w organizmie, mogą być - w zależności od całokształtu okoliczności - uznane za podjęte przy użyciu nadmiernego dla tego pracownika wysiłku.” W omawianej jednak wcześniej sprawie najważniejszym elementem, na którym

\footnotetext{
${ }^{16}$ Wyrok SN z dnia 6 sierpnia 2014r., II UK 518/13, LEX nr 1504564.

${ }^{17}$ Postanowienie SN z dnia 16 stycznia 2014 r., I PK 185/13, LEX nr 1646046.
} 
wskazał SN było niezapewnienie należytej opieki medycznej przez pracodawcę. Jak wynika z opisanego stanu faktycznego, pracodawca poprzez swoje zachowanie mógł doprowadzić do nasilenia skutków udaru, o czym świadczyła także opinia biegłego neurologa.

Interesującym zagadnieniem jest występowanie u pracownika zarówno przyczyny zewnętrznej, jak i wewnętrznej. Otóż z orzecznictwa wynika, iż „przyczyna wypadku nie musi być jedna, lecz w katalogu przyczyn zdarzenia przyczyny zewnętrzne mogą występować obok wewnętrznych"18 Nadto, do uznania zdarzenia za wypadek przy pracy dostatecznym jest, by działanie przyczyny zewnętrznej miało chociaż pośredni wpływ na skutek. ${ }^{19}$ Wskazuje na to, m.in. wyrok SN z dnia 9 grudnia 2015 r. ${ }^{20} . \therefore$, Tymczasem, nagłe zdarzenie wywołane intensywnym ujawnieniem się gwałtownego lub zaostrzonego stadium samoistnej zagrażającej życiu pracownika choroby lub chorób wewnętrznych (tkwiących w organizmie pracownika) może być uznane za wypadek przy pracy tylko wtedy gdy pozostaje w związku miejscowym, czasowym oraz przyczynowo-skutkowym $\mathrm{z}$ wykonywaniem pracy lub warunkami jej wykonywania, która powinna stanowić zewnętrzną współprzyczynę zdarzenia wypadkowego w jej nagłym oraz intensywnie niekorzystnym oddziaływaniu na organizm pracownika. Konkretnie rzecz ujmując, ustalenie wypadku przy pracy pracownika dotkniętego istotnym schorzeniem wewnętrznym jest możliwe tylko wtedy, gdyby bez świadczenia wykonywanego zatrudnienia nie doszło do gwałtownego pogorszenia się stanu chorobowego i nagłego zdarzenia o cechach wypadku przy pracy. (...) Tylko zatem wykazanie, że bez przyczyny zewnętrznej, wynikającej lub związanej z wykonywaniem pracy lub oddziaływaniem szkodliwego środowiska zatrudnienia $\mathrm{w}$ dniu zdarzenia, nie doszłoby w czasie i miejscu pracy do nagłego i gwałtownego ujawnienia lub pogorszenia się choćby wcześniej bezobjawowych, utajonych lub "ukrytych" schorzeń wewnętrznych, uprawniałoby uznanie zdarzenia za wypadek przy pracy, może uzasadniać przyznanie świadczeń powypadkowych po ustaleniu wypadku przy pracy."

Co ciekawe, przyczynę zewnętrzną wypadku przy pracy może stanowić także dopuszczenie pracownika do wykonywania pracy na określonym stanowisku na podstawie aktualnego, lecz oczywiście błędnego orzeczenia lekarskiego. Wynika to z ponoszonego przez pracodawcę ryzyka związanego z zatrudnianiem pracownika. Warto przywołać w tym kontekście wyrok z 18 stycznia 2017 r. $^{21}$, w którego argumentacji przywołano dwa zgoła

\footnotetext{
${ }^{18}$ Wyrok SN z dnia 24 kwietnia 2018 r., III PK 45/17, LEX nr 2553861.

${ }^{19}$ I. Jędrasik-Jankowska, Pojęcie i konstrukcje prawne..., s. 414.

${ }^{20}$ Wyrok SN z dnia 9 grudnia 2015 r., I UK 22/15, LEX nr 1940047.

${ }^{21}$ Wyrok SN z dnia 18 stycznia 2017 r., III PK 50/16, LEX nr 2261777.
} 
odmienne poglądy na powyższą problematykę. Pierwszy to wyrok z 23 kwietnia $1997 \mathrm{r}^{22}$, w którym SN sformułował opinię, że aktualne ale wadliwe orzeczenie lekarskie wyklucza podjęcie przez pracodawcę uznaniowej decyzji o dopuszczeniu pracownika do wykonywania obowiązków służbowych. Wskazano, że ,, świetle art. $22 \S 1$ k.p. pracodawca jest bowiem nie tylko wierzycielem pracownika, ale i jego dłużnikiem zobowiązanym do zatrudnienia pracownika na określonym w umowie stanowisku, jeśli nie istnieją wynikające z orzeczenia lekarskiego przeciwwskazania do wykonywania owej pracy." Nieco inne wnioski zawarł SNw dwóch kolejno cytowanych wyrokach ${ }^{23}$. Najprościej mówiąc wynika z nich, iż obowiązek dopuszczenia do wykonywania pracy nie jest bezwzględny, nawet jeśli pracownik legitymuje się aktualnym wynikiem badań profilaktycznych. Natomiast SN w wyroku z 2017 r. przychylił się do stwierdzenia, że dopuszczenie pracownika do wykonywania pracy na podstawie aktualnego, ale oczywiście błędnego orzeczenia, stwarza zagrożenie niemniejsze niż zadziałanie pozostałych czynników, uważanych za przyczyny zewnętrzne wypadku przy pracy.

\section{Związek zdarzenia z pracą}

Kolejnym elementem definicji jest kwestia związku zdarzenia z pracą. Stanowi to zarazem kolejny problem wielokrotnie rozpatrywany na gruncie orzecznictwa sądowego. W doktrynie związek zdarzenia $\mathrm{z}$ pracą został nazwany związkiem normatywnym, ponieważ to ustawodawca określił okoliczności, które uznaje za chronione. Ponownie należy w tym miejscu przywołać art. 3 ustawy wypadkowej, który określa zdarzenia mające związek $\mathrm{z}$ pracą, a zatem takie, które nastąpiły: podczas lub w związku z wykonywaniem przez pracownika zwykłych czynności lub poleceń przełożonych, czynności na rzecz pracodawcy, nawet bez polecenia oraz $\mathrm{w}$ czasie pozostawania przez pracownika $\mathrm{w}$ dyspozycji pracodawcy w drodze między siedzibą pracodawcy a miejscem wykonywania obowiązku wynikającego ze stosunku pracy. Warunki te zostały wyliczone alternatywnie, a zatem dla stwierdzenia związku zdarzenia z pracą wystarczy uargumentowanie jednego z wymienionych. ${ }^{24}$

Poprzez zwykłe czynności rozumie się wszelkie czynności niezbędne do wykonywania umówionego rodzaju pracy. Często są one wymienione w umowie o pracę lub wykazie obowiązków pracownika na danym stanowisku. Przez polecenie przełożonego

\footnotetext{
${ }^{22}$ Wyrok SN z dnia 23 kwietnia 1997r., II UKN 76/97, LEX nr 31217.

${ }^{23}$ Wyrok SN z dnia 18 sierpnia 1999r., II UKN 89/99, LEX nr 38006; Wyrok SN z dnia 23 listopada 1999 r., II UKN 208/99, LEX nr 45523.

${ }^{24}$ L. Malkiewicz, P. Drożdż, Wypadek przy pracy z punktu widzenia prawa i medycyny, „Zeszyty Naukowe Państwowej Wyższej Szkoły Zawodowej im. Witelona w Legnicy, nr 6/2010, s. 127-128.
} 
rozumie się natomiast wszelkie polecenia zwierzchnika, dotyczące pracy, które nie są sprzeczne z przepisami prawa oraz umową o pracę. ${ }^{25}$

W orzecznictwie bardzo często przywołuje się ramy, które zakreślają związek zdarzenia $\mathrm{z}$ pracą, a mianowicie występowanie związku czasowego, miejscowego lub funkcjonalnego. Omawia je m.in. wyrok z dnia 8 listopada $2012 r{ }^{26}$ Nota bene Sąd Najwyższy rozpatruje w nim bardzo interesującą sprawę. Otóż, na terenie zakładu pracy, a dokładniej w łaźni górniczej doszło do pobicia pracownika przez innego zatrudnionego, w wyniku czego poszkodowany doznał złamania kości nosowej oraz korony zębów. Sąd Najwyższy uznał, że niewątpliwie zdarzenie to należy uznać za wypadek przy pracy, dlatego że pracownicy przebywali na terenie zakładu pracy, a powodem kłótni i pobicia był konflikt dotyczący sposobu wykonywania obowiązków pracowniczych przez sprawcę zdarzenia. W wyroku tym precyzyjnie określono wymienione wcześniej związki. SN opisał je następująco: „Czasowy związek zdarzenia z pracą polega na tym, że zdarzenie powinno nastąpić albo w czasie wykonywania przez pracownika zwykłych czynności lub poleceń przełożonych, ewentualnie w czasie wykonywania czynności na rzecz pracodawcy, nawet bez polecenia lub w związku $\mathrm{z}$ wykonywaniem tych czynności albo w czasie pozostawania pracownika $\mathrm{w}$ dyspozycji pracodawcy $\mathrm{w}$ drodze między siedzibą pracodawcy a miejscem wykonywania obowiązku wynikającego ze stosunku pracy. Funkcjonalny związek zdarzenia z pracą wyraża się w tym, że zdarzenie powinno nastąpić w czasie lub w związku z wykonywaniem przez pracownika określonych czynności, "zwykłych czynności lub poleceń przełożonych", "czynności na rzecz pracodawcy, nawet bez polecenia", a także "w czasie pozostawania w dyspozycji pracodawcy". Wreszcie miejscowy związek zdarzenia z pracą polega na tym, że zdarzenie następuje w miejscu, które jest albo miejscem wykonywania czynności służbowych albo miejscem na "drodze między siedzibą pracodawcy a miejscem wykonywania obowiązku wynikającego ze stosunku pracy". Jak doskonale można zauważyć opisane powyżej zdarzenie spełnia wszystkie te kryteria.

Wielokrotnie rozpatrywaną kwestią jest zerwanie związku z pracą. Może ono nastąpić także pomimo przebywania pracownika na terenie zakładu pracy, ale w momencie kiedy przenosi się on w sferę spraw prywatnych. Często ma to związek z wprowadzeniem się przez pracownika w stan nietrzeźwości. Należy jednak zauważyć, że obecnie Sąd Najwyższy ma stosunkowo liberalne podejście do takiej sytuacji, bowiem przyjmuje się, że o zerwaniu związku z pracą decyduje nie tylko wyżej wymieniony stan, lecz także inne okoliczności.

\footnotetext{
${ }^{25}$ Z. Salwa, Pojęcie wypadku przy pracy, „Praca i Zabezpieczenie Społeczne” 3/2003, s. 20.

${ }^{26}$ Wyrok SN z dnia 8 listopada 2012r., II PK 80/12, LEX nr 1255858.
} 
W rozpatrywanej w wyroku z 6 marca 2014 r. $^{27}$ sprawie pracownik uległ śmiertelnemu wypadkowi, w czasie korzystania $\mathrm{z}$ firmowego transportu $\mathrm{w}$ drodze między siedzibą pracodawcy a miejscem wykonywania obowiązku wynikającego ze stosunku pracy. Wraz z innymi pracownikami wcześniej zakupił i spożywał alkohol, wprawiając się w stan nietrzeźwości. Sąd Najwyższy po rozpatrzeniu stanu faktycznego stwierdził, iż: „Wprawienie się pracownika w stan nietrzeźwości w czasie odbywania drogi z miejsca wykonywania obowiązków wynikających ze stosunku pracy do siedziby pracodawcy środkiem lokomocji należącym do pracodawcy i kierowanym przez innego pracownika nie wyłącza pozostawania pracownika w dyspozycji pracodawcy w rozumieniu art. 3 ust. 1 pkt 3 ustawy wypadkowej. Pracownik musi być jednak gotowy (zdolny) do wykonywania czynności związanych z przejazdem (drogą) oraz czynności, które ma wykonać w siedzibie pracodawcy. W szczególności musi być w tym czasie zdolny do wykonywania poleceń dotyczących przejazdu wydawanych przez osoby działające w imieniu pracodawcy. Znaczny stan nietrzeźwości może bowiem oznaczać całkowite zerwanie normatywnego związku zdarzenia z pracą, a w tym przypadku z drogą z miejsca świadczenia pracy do siedziby pracodawcy”. Można zatem stwierdzić, że jeżeli wprawienie się przez pracownika w stan nietrzeźwości, zważywszy na inne okoliczności sprawy, nie doprowadzi do zerwania związku z pracą, to nie będzie mieć wpływu na wystąpienie wypadku przy pracy. Z tej przyczyny każdą taką sytuację należy badać indywidualnie, aby wykluczyć ewentualne zerwanie związku z pracą.

Ciekawym orzeczeniem podejmującym problematykę zerwania związku z pracą jest też wyrok SN z 17 września 2008r. ${ }^{28}$ Sprawa dotyczyła udziału pracownika naukowodydaktycznego przebywającego na zwolnieniu lekarskim w czynnościach opiniodawczych poprzedzających wybory do władz uczelni, a który na terenie zakładu pracy zadławił się pączkiem w wyniku czego zmarł. Sądy obu instancji stwierdziły, że przebywanie na terenie zakładu pracy po wykonaniu przez pracownika czynności na rzecz pracodawcy wyklucza istnienie związku zdarzenia z wykonywanymi czynnościami. Sąd Najwyższy jednak przekazał sprawę do ponownego rozpoznania i w świetle wskazanego stanu faktycznego wskazał, że " niezbędne dla wyjaśnienia przedmiotowej sprawy są szczegółowe ustalenia dotyczące momentu rozpoczęcia sondażu i chwili oddania głosu przez poszkodowanego, jak również w ogólności przebiegu tej procedury(...) Są one niezbędne dla dokonania oceny, czy poszkodowany udał się do bufetu już po zakończeniu uczestnictwa w sondażu, czy też (...) udał się tam jedynie w czasie przerwy w tych czynnościach. Przyjęcie tej drugiej możliwości

\footnotetext{
${ }^{27}$ Wyrok SN z dnia 6 marca 2014 r., I PK 198/13, LEX nr 1463666.

${ }^{28}$ Wyrok SN z dnia 17 września 2008r., I UK 66/08, LEX nr 558205.
} 
wskazywałoby, mając na uwadze specyfikę zatrudnienia pracowników naukowodydaktycznych uczelni, że związek z pracą nie uległ zerwaniu, a zdarzenie do jakiego doszło w bufecie należy ocenić jako wypadek przy pracy."

\section{Skutek w postaci szkody jaką jest uraz lub śmierć}

Ostatnim elementem tworzącym pojęcie wypadku przy pracy w świetle obowiązującej definicji stanowi szkoda. Jak już wcześniej wspomniano, czynnik ten został dodany dopiero na gruncie aktualnej ustawy wypadkowej. Wprowadzenie do przepisu prawnego szkody z jednej strony spowodowało, że zmienił się przedmiot definicji (zdarzenie fizyczne powodujące szkodę), z drugiej natomiast ograniczono w ten sposób zakres ochrony jedynie do urazu fizycznego bądź śmierci. ${ }^{29}$ Szkoda może stanowić natychmiastowy skutek wypadku, ale możliwe jest także je wystąpienie w późniejszym okresie.

\section{Zakończenie}

Problematyka wypadków przy pracy jest wielokrotnie podejmowana w różnego rodzaju publikacjach naukowych. Sądzę jednak, że warto pochylić się szczególnie nad kazuistycznymi przypadkami życia codziennego, stąd uważam też, że nie sposób jest wyczerpać wspomnianą tematykę, a kolejne opracowania pozwalają poznać nowe zagadnienia z tym związane. Dlatego też niemal każda sytuacja rozpatrywana przez sąd wymaga gruntownego przeanalizowania wszelkich aspektów związanych z definicją wypadku przy pracy.

Z powyższego wywodu można wyciągnąć kilka wniosków. Przede wszystkim, mimo stosowania coraz lepszych sprzętów czy uświadamiania pracowników w zakresie bezpieczeństwa i higieny pracy nadal liczba wypadków przy pracy jest wysoka. Należy bowiem podkreślić, iż nawet najlepiej opracowane zasady funkcjonowania w zakładzie pracy lub przepisy ochronne nie gwarantują jego uniknięcia. Według danych Głównego Urzędu Statystycznego $^{30}$ w samym 2019 r. zgłoszono 83205 osób poszkodowanych w wypadkach przy pracy, z czego 0,2\% stanowiły ofiary śmiertelne.

Wyroki Sądu Najwyższego zwykle w kwestii wypadków przy pracy tworzą w miarę jednolitą linię orzeczniczą. Można jednak zadać sobie pytanie czy SN powinien dążyć do jednoznacznego sprecyzowania tego pojęcia? W mojej ocenie problematyka wypadków przy pracy jest o tyle rozbudowana, iż można przypuszczać, że stworzenie jednolitego

\footnotetext{
${ }^{29}$ I. Jędrasik-Jankowska, Pojęcia i konstrukcje prawne..., s.417.

${ }^{30}$ www.stat.gov.pl [dostęp: 09.08.2020 r.].
} 
orzecznictwa jest po prostu niemożliwe. W opracowaniu tym wskazano jedynie kilkanaście wyroków, które w określony sposób opisywały elementy pojęcia wypadku przy pracy, a już na tym gruncie pojawiały się wątpliwości interpretacyjne. Choć nie wyczerpuje to nawet skrawka złożoności zagadnienia, może stanowić pierwsze zetknięcie się z omawianym pojęciem.

\section{Bibliografia:}

\section{Literatura}

Dunaj B., Stownik języka polskiego, Wydawnictwo Twoje Książki, Warszawa 2008

Florek L., Prawo pracy, Wydawnictwo C.H.Beck, Warszawa 2016

Góraj A., Wypadek przy pracy - sytuacja prawna ubezpieczonego w świetle aktualnej definicji, „Przegląd Prawniczy Uniwersytetu Warszawskiego Rok XVI, nr 1/2017

Jachimowicz M., Wypadki przy pracy i choroby zawodowe. Świadczenie ubezpieczeniowe i cywilne, wyd. Difin, Warszawa 2013

Jędrasik-Jankowska I., Pojęcia i konstrukcje prawne ubezpieczenia społecznego, wyd. Wolters Kluwer, Warszawa 2018

Malkiewicz L., Drożdż P., Wypadek przy pracy z punktu widzenia prawa i medycyny, „Zeszyty Naukowe Państwowej Wyższej Szkoły Zawodowej im. Witelona w Legnicy, nr 6/2010

Salwa Z., Pojęcie wypadku przy pracy, „Praca i zabezpieczenie społeczne” 3/2003 www.stat.gov.pl

\section{Akty prawne}

Ustawa z dnia 26 czerwca 1974 r. Kodeks pracy, t.j. Dz. U. z 2020 r. poz. 1320.

Ustawa z dnia 28 marca 1933r. o ubezpieczeniu społecznym, Dz.U. 1933 nr 51 poz. 396

Dekret z dnia 25 czerwca 1954 r. o powszechnym zaopatrzeniu emerytalnym pracowników i ich rodzin, Dz. U. $1954 \mathrm{nr} 30$ poz. 116

Ustawa z dnia 30 października 2002 r. o ubezpieczeniu społecznym z tytułu wypadków przy pracy i chorób zawodowych (Dz. U. 2002 nr 199 poz. 1673)

\section{Orzecznictwo}

Wyrok SN z dnia 5 października 2012 r., I UK 197/12, LEX nr 1303225

Wyrok SN z dnia 4 października 2006 r., II UK 40/06, LEX nr 309429

Wyrok SN z dnia 11 stycznia 2013r., II UK 162/12, LEX nr 1314610

Wyrok SN z dnia 6 sierpnia 2014r., II UK 518/13, LEX nr 1504564

Postanowienie SN z dnia 16 stycznia 2014 r., I PK 185/13, LEX nr 1646046

Wyrok SN z dnia 24 kwietnia 2018 r., III PK 45/17, LEX nr 2553861

Wyrok SN z dnia 9 grudnia 2015 r., I UK 22/15, LEX nr 1940047

Wyrok SN z dnia 18 stycznia 2017 r., III PK 50/16, LEX nr 2261777

Wyrok SN z dnia 23 kwietnia 1997r., II UKN 76/97, LEX nr 31217

Wyrok SN z dnia 18 sierpnia 1999r., II UKN 89/99, LEX nr 38006

Wyrok SN z dnia 23 listopada 1999 r., II UKN 208/99, LEX nr 45523

Wyrok SN z dnia 8 listopada 2012r., II PK 80/12, LEX nr 1255858

Wyrok SN z dnia 6 marca 2014 r., I PK 198/13, LEX nr 1463666

Wyrok SN z dnia 17 września 2008r., I UK 66/08, LEX nr 558205. 